\title{
NON-RADIOMETRIC IMMUNOASSAYS [FLUOROIMMUNOASSAY (FIA) AND FLUOROMETRIC ENZYME IMMUNOASSAY (FEIA)] WITH RADIOIMMUNOASSAY (RIA) FOR EVALUATION OF ADRENAL FUNCTION IN NORMAL AND HYPERCORTISOLEMIC DOGS
}

\author{
MÉTODOS DE IMUNOENSAIO NÃO-RADIOMÉTRICOS [FLUOROIMUONOENSAIO \\ (FIE) E ENZIMAIMUNOENSAIO (EIE)] E O RADIOIMUNOENSAIO (RIE) NA \\ AVALIAÇÃO DA FUNÇÃO ADRENAL DE CÃES NORMAIS E CÃES COM \\ HIPERADRENOCORTICISMO
}

\author{
Márcia Marques Jericó ${ }^{1}$ Berenice Bilharino de Mendonça ${ }^{2}$ \\ Mary Otsuka ${ }^{3}$ Aristides Maganin $\mathbf{J r}^{4}$ Carlos Eduardo Larsson
}

SUMMARY

Non-radiometric immunoassays offer many advantages over radiometric assays, such as higher stability of kit compounds and absence of potential hazardous effects for users and environment. The comparison of cortisol measurements by fluoroimmunoassay (FIA) and fluorometric enzyme immunoassay (FEIA) with radioimmunoassay (RIA) in adrenal function evaluation of normal $(n=50)$ and hypercortisolemic dogs $(n=12)$ was proposed. Serum concentrations of cortisol were measured in basal conditions and 8 hours after dexamethasone (DEX) suppression $(0.01 \mathrm{mg} / \mathrm{kg} / \mathrm{IV})$. All our reference values were based on the $5^{\text {th }}$ and $95^{\text {th }}$ percentile. The values for basal cortisol of healthy dogs were 0.20 to $2.35 \mu \mathrm{g} / \mathrm{d} \ell$ for FIA, 0.30 to $5.39 \mu \mathrm{g} / \mathrm{d} \ell$ for FEIA, and 0.65 to $4.64 \mu \mathrm{g} / \mathrm{d} \ell$ for RIA. After DEX suppression the values were $\leq 0.87 \mu \mathrm{g} / \mathrm{d} \ell, \leq 0.30 \mu \mathrm{g} / \mathrm{d} \ell$ and $\leq 0.80 \mu \mathrm{g} / \mathrm{d} \ell$ for FIA, FEIA and RIA, respectively. In hypercortisolemic dogs, the values of cortisol (mean $\pm S D$ ) in basal and post-DEX conditions were $2.71 \pm 0.41 \mu \mathrm{g} / \mathrm{d} \ell$ and $1.73 \pm 1.15 \mu \mathrm{g} / \mathrm{d} \ell$ for FIA, $7.05 \pm$ $2.85 \mu \mathrm{g} / \mathrm{d} \ell$ and $4.93 \pm 2.26 \mu \mathrm{g} / \mathrm{d} \ell$ for FEIA, and $4.80 \pm 1.43 \mu \mathrm{g} / \mathrm{d} \ell$ and $3.52 \pm 1.08 \mu \mathrm{g} / \mathrm{d} \ell$ for RIA. Statistically significant differences $(p<0.05)$ between the normal and the hypercortisolemic groups (Kruskal-Wallis test) were observed in the three methods, and between basal and post-DEX values (Wilcoxon test) using RIA and FEIA methods but not with FIA. Cortisol determinations by FEIA and RIA methods at DEX suppression test showed 100\% of sensitivity and specificity for the diagnosis of hyperadrenocorticism in dogs. The results demonstrate that serum cortisol concentrations measurements by FEIA is a suitable alternative to the traditional RIA method for adrenal function evaluation in dogs.

Key words: fluoroimmunoassay, enzyme immunoassay, radioimmunoassay, dogs, hyperadrenocorticism

RESUMO

Os métodos de dosagem hormonal por técnicas nãoradioativas apresentam inúmeras vantagens sobre os que utilizam radioisótopos como marcadores de hormônios ou anticorpos. Dentre tais vantagens, incluem-se maior meia-vida útil dos

\footnotetext{
${ }^{1}$ Graduate student at Internal Medicine Departament of Faculdade de Medicina Veterinária e Zootecnia, Universidade de São Paulo (FMVZ/USP). Professor of Internal Medicine in Small Animal at Faculdade de Medicina Veterinária, Universidade Santo Amaro (FMV/UNISA) and Faculdade de Medicina Veterinária, Universidade Bandeirantes (FMV/UNIBAN). Rua: Joaquim Antunes, nº611/ap.62, 05415-011, São Paulo, SP. E-mail: marciajerico@ hotmail.com. Author for correspondence.

${ }^{2}$ Associate Professor at the Laboratory of Hormones and Molecular Genetics (LIM/42) of the Discipline of Endocrinology of Faculdade de Medicina da Universidade de São Paulo (FM/USP).

${ }^{3}$ Veterinarian at Dermatology Departament of Veterinary Hospital of FMVZ/USP.

${ }^{4}$ HEAD - veterinarian at Kennel of the Policia Militar do Estado de São Paulo.

${ }^{5}$ Full Professor at Internal Medicine Departament of FMVZ/USP.
} 
reagentes por maior estabilidade dos compenentes, inexistência de riscos de contaminação radioativa, tanto pessoal quanto ambiental. Para avaliar a aplicação destes novos métodos na prática da endocrinologia clínica de pequenos animais, comparamos o método de radioimunoensaio (RIE) aos métodos alternativos fluoroimunoensaio (FIE) e enzimaimunoensaio (EIE) na avaliação da função adrenal canina. Para tanto, padronizaram-se os níveis de cortisol em cães normais $(n=50) e$ em cães com hiperadrenocorticismo $(n=12)$, sob condições basais $e$ oito horas após supressão com dexametasona (DEX) $(0,01 \mathrm{mg} / \mathrm{kg} I V)$. Os valores do grupo de animais controle compreendidos entre os percentis 5 a 95 foram estabelecidos como normais. Os valores de cortisol basal foram de 0,20 a

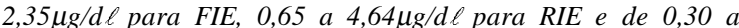
$5,39 \mu \mathrm{g} / \mathrm{d} \ell$ para EIE. Após supressão com DEX, os valores do grupo controle foram $<0,87 \mu \mathrm{g} / \mathrm{d} \ell$ para $\mathrm{FIE},<0,80 \mu \mathrm{g} / \mathrm{d} \ell$ para

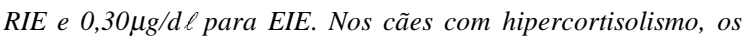
valores de média e desvio padrão dos níveis de cortisol em condições basais e pós-supressão com DEX foram de 2,71 \pm $0,41 \mu \mathrm{g} / \mathrm{d} \ell$ e $1,73 \pm 1,15 \mu \mathrm{g} / \mathrm{d} \ell$ (FIE), 7,05 $\pm 2,85 \mu \mathrm{g} / \mathrm{d} \ell$ e 4,93 \pm 2,26 $\mu \mathrm{g} / \mathrm{d} \ell$ (EIE), e 4,80 $\pm 1,43 \mu \mathrm{g} / \mathrm{d} \ell$ e 3,52 $\pm 1,08 \mu \mathrm{g} / \mathrm{d} \ell(\mathrm{RIE})$, respectivamente. Os resultados obtidos pelos três métodos (RIE, FIE, EIE) foram comparados, de forma a se averiguar a sua confiabilidade para o diagnóstico do hiperadrenocorticismo endógeno, no que tange às suas características de sensibilidade e especificidade. Desta forma, na avaliação da função adrenal, os métodos de EIE e RIE apresentam desempenhos semelhantes, considerados ideais (ambos com $100 \%$ de sensibilidade $e$ especificidade). Concluiu-se que o método de EIE, para avaliação da função adrenal, mostrou-se tão adequado quanto o tradicional método de RIE para as determinações de cortisol.

Palavras-chave: fluoroimunoensaio, enzimaimunoensaio, cães, radioimunoensaio, hiperadrenocorticismo.

\section{INTRODUCTION}

Canine hyperadrenocorticism is a common endocrine disorder caused by the excessive cortisol secretion by the adrenal cortex. Approximately $85 \%$ of hypercortisolemic dogs have excessive adrenocorticotropic hormone (ACTH) secretion from the pituitary gland, resulting in bilateral adrenocortical hyperplasia. The other $15 \%$ have adrenocortical tumors, which autonomously secrete excess amounts of cortisol (MACK \& FELDMAN, 1990; FELDMAN \& NELSON, 1996). Diagnosis of canine hyperadrenocorticism is based on history, physical examination, results of routine laboratory tests $(\mathrm{CBC}$, serum biochemical analysis, and urinalysis) along with serum cortisol determinations from specific pituitary-adrenal function tests, such as the low-dose dexamethasone suppression test (KAPLAN et al., 1995).

Accurate measurements of serum cortisol have been made by radioimmunoassay (RIA) since the 1970s. However, recently developed nonradiometric immunoassays offer many advantages over RIA kits: (a) they share the characteristics of specificity, sensitivity and speed of the isotopic techniques; (b) the assay compounds are stable for relatively long periods and there are no health hazards for users and environment and (c) special training and licenses associated with the use of radioactive material are not required (GIEGEL $\boldsymbol{e t} \boldsymbol{a l}$., 1982; SOINI \& KOJOLA, 1983; LÖVGREN et al.; 1984; ALBERTSON, 1990; PETTERSON, 1993).

The purpose of this study is the comparison of cortisol measurements by fluoroimmunoassay (FIA) and fluorometric enzyme immunoassay (FEIA) with radioimmunoassay (RIA) in the evaluation of adrenal function in normal and hypercortisolemic dogs.

\section{MATERIAL AND METHODS}

Dogs- Fifty healthy dogs (25 males and 25 females) from the Police Force kennel were used as normal control (Group N). Other $12 \mathrm{dogs}$ were referred to the Veterinary Hospital of the University of São Paulo, with clinical signs of hypercortisolism. Preliminary routine laboratory results and adrenal evaluation, combined with positive response to the therapy with mitotane were compatible with hyperadrenocorticism diagnosis (Group HC). Both groups were submitted to the low-dose dexamethasone suppression test (baseline cortisol measurements and 8 hours after $0.01 \mathrm{mg} / \mathrm{kg}$ of dexamethasone/IV).

Cortisol measurements- Serum cortisol concentration was determined by commercial kits of radioimmunoassay $^{\mathrm{a}}$ (RIA), fluoroimmunoassay ${ }^{\mathrm{b}}$ (FIA) and fluorometric enzyme immunoassay ${ }^{c}$ (FEIA), according to the manufacturer's instructions. All samples were analyzed in duplicate. The classic RIA method ( ${ }^{125}$ labelled), which uses rabbit polyclonal antibodies, detected concentrations down to $0.21 \mu \mathrm{g} / \mathrm{d} \ell$, with inter and intra-assay coefficients of variation which were $<8.3 \%$. Cortisol determinations by FIA method, a solid phase time-resolved fluoroimmunoassay based on the competitive reaction between europium-labelled and non-labelled cortisol for a limited amount of binding sites on cortisol specific mouse monoclonal antibodies. The assay detected cortisol concentrations down to $0.20 \mu \mathrm{g} / \mathrm{d} \ell$, with inter and intra-assay coefficients of variation $<3.2 \%$. The FEIA cortisol measurements, also based on competitive reaction by rabbit policlonal antibodies between the sample cortisol and the labelled cortisol with calf intestinal alkaline phosphatase (that will produce fluorescence when it reacts with the appropriate substrate), resulted in sensitivity level of $0.3 \mu \mathrm{g} / \mathrm{d} \ell$ and inter and intraassay coefficients of variation $<6.3 \%$.

Statistical analysis- The results of the 2 groups (normal and hypercortisolemic dogs) were compared by non-parametric statistical analysis, including the Kruskal-Wallis, Wilcoxon and Friedman tests. Sensitivity and specificity were also calculated for basal and post-DEX measurements, for each one of the three immunoassays evaluated. 


\section{RESULTS}

The results are shown in tables 1 and 2 and in figures 1 and 2 . Reference values for basal cortisol of healthy dogs on the $5^{\text {th }}$ and $95^{\text {th }}$ percentile were: 0.20 to $2.35 \mu \mathrm{g} / \mathrm{d} \ell$ for FIA, 0.30 to $5.39 \mu \mathrm{g} / \mathrm{d} \ell$ for FEIA, and 0.65 to $4.64 \mu \mathrm{g} / \mathrm{d} \ell$ for RIA. After dexamethasone suppression the values on the $95^{\text {th }}$ percentile were $\leq 0.87 \mu \mathrm{g} / \mathrm{d} \ell$ for FIA, $\leq$ $0.30 \mu \mathrm{g}$ for FEIA and $\leq 0.80 \mu \mathrm{g} / \mathrm{d} \ell$ for RIA. The Wilcoxon test showed a statistically significant difference $(p<0.05)$ between the basal and after dexamethasone suppression cortisol values for all methods in Groups $\mathrm{N}$ and HC, except for FIA in Group N ( $>0.179)$. The Kruskall-Wallis test showed that the three methods are able to differentiate normal from hypercortisolemic dogs, for baselines as well post-DEX values. The Friedman test showed that the values of cortisol are statistically different among the three methods, either for basal or post-DEX results. Sensitivity and specificity of $100 \%$ of the dexamethasone suppression test for the diagnosis of hyperadrenocorticism in dogs was achieved with cortisol determinations done by both FEIA and RIA methods, when compared Groups N and HC.

\section{DISCUSSION}

Measurement of serum or plasma cortisol concentrations by the low-dose dexamethasone suppression test has been one of the most useful diagnostic tools for the diagnosis of canine hyperadrenocorticism with sensitivity values between 95 and 100\% (FELDMAN \& NELSON,

Table 1 - Results of serum cortisol $(\mu \mathrm{g} / \mathrm{dl})$ concentrations before and $8 \mathrm{~h}$ after dexamethasone suppression $(0.01 \mathrm{mg} / \mathrm{kg} \mathrm{IV})$ measured by fluoroimmunoassay (FIA), radioimmunoassay (RIA) and fluorometric enzyme immunoassay (FEIA), in normal dogs (Group $\mathrm{N}-\mathrm{n}=50$ ) and in dogs with hyperadrenocorticism (Group HC - n=12)

\begin{tabular}{|c|c|c|c|c|c|}
\hline & & \multicolumn{2}{|c|}{ Group N } & \multicolumn{2}{|c|}{ Group HC } \\
\hline \multirow{3}{*}{ FIA } & & Mean \pm S D & $p$ & Mean $\pm S$ D & $p$ \\
\hline & Basal & $0.41 \pm 0.66$ & & $2,71 \pm 1,41$ & \\
\hline & Post DEX & $0.25 \pm 0.27$ & 0.179 & $1,73 \pm 1,15$ & 0.005 \\
\hline \multirow[t]{2}{*}{ RIA } & Basal & $1.44 \pm 1.25$ & & $4,80 \pm 1,43$ & \\
\hline & Post DEX & $0.58 \pm 0.11$ & $<0.001$ & $3,52 \pm 1,08$ & 0.007 \\
\hline \multirow[t]{2}{*}{ FEIA } & Basal & $1.26 \pm 1.65$ & & $7,05 \pm 2,85$ & \\
\hline & Post DEX & $<0.30$ & $<0.001$ & $4,93 \pm 2,26$ & 0.003 \\
\hline
\end{tabular}

(Wilcoxon's test)
Table 2 - Comparison of sensitivity and specificity of basal cortisol and cortisol 8 hours after dexamethasone suppression as determinated by fluoroimmunoassay (FIA), radioimmunoassay (RIA) and fluorometric enzyme immunoassay (FEIA).

\begin{tabular}{lcccccc}
\hline \multicolumn{7}{c}{ ADRENAL FUNCTION } \\
\hline & CORTISOL BASAL & \multicolumn{2}{c}{ CORTISOL POST DEX } \\
\cline { 2 - 7 } & FIA & RIA & EIA & FIA & RIA & EIA \\
\cline { 2 - 7 } & & & & & \\
Sensitivity & $66.7 \%$ & $66.7 \%$ & $66.7 \%$ & $75.0 \%$ & $100 \%$ & $100 \%$ \\
Specificity & $96.0 \%$ & $96.0 \%$ & $96.0 \%$ & $96.7 \%$ & $100 \%$ & $100 \%$ \\
FP $^{(1)}$ & 2 & 2 & 2 & 1 & 0 & 0 \\
FN $^{(2)}$ & 4 & 4 & 4 & 3 & 0 & 0 \\
\hline
\end{tabular}

(1) FP: false positive; (2) FN: false negative

1996; KAPLAN et al., 1995; GUPTILL et al., 1997). A low dose of dexamethasone injection provides enough negative feedback in normal dogs to suppress pituitary ACTH secretion and therefore reduces cortisol concentration within 2 to 3 hours to a less than standard value set by each laboratory. Suppression in normal dogs persists for at least 8 hours and often for several days (FELDMAN \& NELSON, 1996; GUPTILL et al., 1997). All dogs selected for the Group HC, together with their history and clinical signs, exhibited previous results of adrenal function evaluation by the low-dose dexamethasone suppression test which were compatible with endogenous hyperadrenocorticism (according to our reference values). Moreover, they presented positive response to the treatment with mitotane.

Non-radioactive methods of immunoassay have some advantages over RIA because they do not require the handling of radioactive materials. Assay compounds remain stable for relatively long periods, special training and licenses associated with the use of radioactive material are not required and the health hazards are much less likely. (GIEGEL $\boldsymbol{e t}$ al., 1982; SOINI \& KOJOLA, 1983; LÖVGREN et al.; 1984; ALBERTSON, 1990; PETTERSON, 1993. Very limited information is available on the measurement of cortisol concentrations by the modern non-isotopic immunoassays methods in dogs, and the few reported studies focused on the iodothironines (PARADIS et al., 1996; THORESEN et al., 1996) or canine prolactin (HOIER \& JENSEN, 1996). To the authors' knowledge, no published data are available on the determination of cortisol concentrations by FIA or FEIA in the canine serum (baseline or after dexamethasone administration values).

The results show that measurements of serum cortisol concentrations by FIA, RIA or FEIA in the low-dose dexamethasone suppression test are able to differentiate normal from 


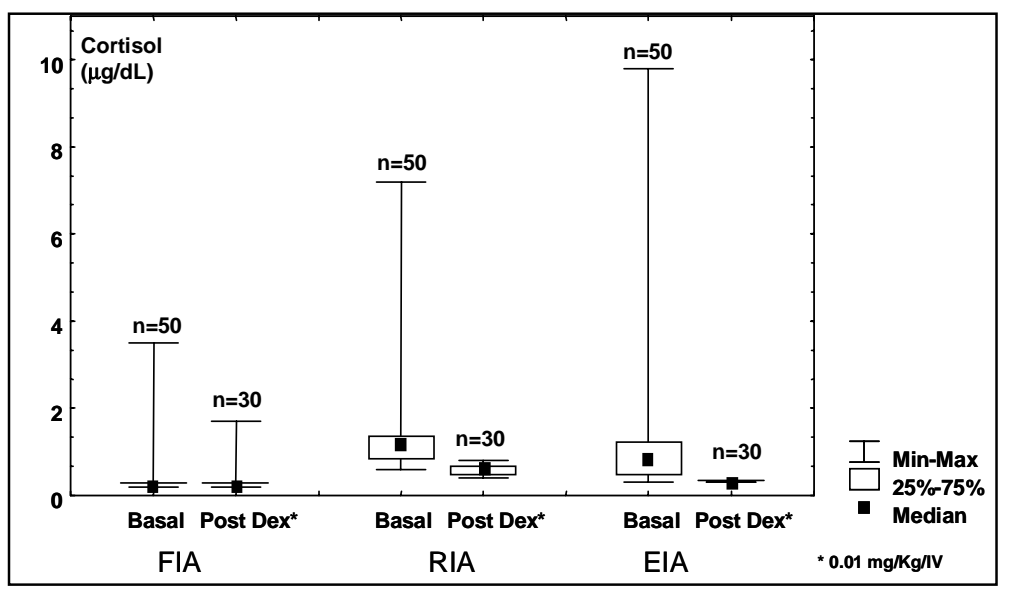

Figure 1 - Basal serum cortisol concentrations and 8 hrs after dexamethasone (Dex) in normal dogs (Group N), measured by fluoroimmunoassay (FIA), radioimmunoassay (RIA) and fluorometric enzyme immunoassay (FEIA).

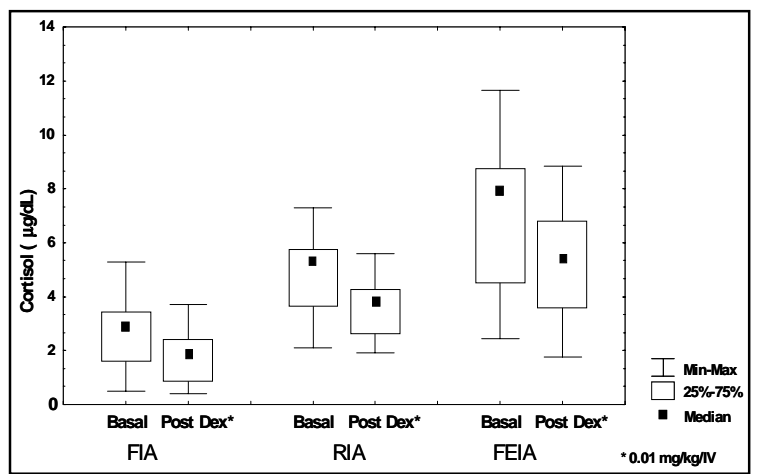

Figure 2 - Serum cortisol concentrations in 12 dogs with hyperadrenocorticism (Group HC), basal and $8 \mathrm{hrs}$ after dexamethasone (Dex), measured by fluoroimmunoassay (FIA), radioimmunoassay (RIA) and fluorometric enzyme immunoassay (FEIA).

hypercortisolemic dogs. On the other hand, baseline and post DEX FIA cortisol values were not different in the normal group. FIA cortisol values were the lowest in both groups when compared to RIA and FEIA methods. This fact probably interfered with the sensitivity and specificity of the FIA method. The FEIA method showed similar results to RIA regarding sensitivity and specificity (both with $100 \%$ on post-DEX values), when compared to the groups of normal and hypercortisolemic dogs.

In this paper the reference values for cortisol levels were established by the three methods, in basal conditions and after low dose dexamethasone suppression. The authors conclude that serum cortisol measured by FEIA may be a valuable alternative to the traditional radioactive method.

\section{ACKNOWLEDGMENTS}

We are thankful to the command of the Police Force of the state of São Paulo for their permission to use their dogs as the normal group and to the veterinarians and technicians at the Veterinary Hospital and the Hormonal Analysis Laboratory for their support.

\section{SOURCES AND MANUFACTURERS}

${ }^{\mathrm{a} G a m m a}$ Coat [125I] Cortisol RIA Kit, INCSTAR, USA

${ }^{\text {b} A U T O D E L F I A ~ C o r t i s o l ~ K i t, ~ W a l l a c, ~ F i n l a n d ~}$ ${ }^{\mathrm{c} S t r a t u s}$ Cortisol Fluorometric Enzyme Immunoassay, Dade, USA.

\section{REFERENCES}

ALBERTSON, B.D. Hormonal assay methodology present and future prospects. Clin Obstet Gynecol, v.33, n.3, p.591-610, 1990.

FELDMAN, E.C., NELSON, R.W. (eds.) Canine and feline endocrinology and reproduction. Philadelphia : Saunders, 1996. $785 \mathrm{p}$.

GIEGEL, J.L., BROTHERTON, M.M., CRONIN, P., et al. Radial partition immunoassay. Clin Chem, v.28, p.9, p.1894-1898, 1982.

GUPTILL, L., SCOTT-MONCRIEFF, J.C., WIDMER, W.R. Diagnosis of canine hyperadrenocorticism. Vet Clin North Am Small Anim Pract, 27, p. 215-235, 1997.

HOIER, R., JENSEN, A.L. Determination of canine prolactin by use of a commercial heterologous enzymeimmunoassay kit. J Vet Med, v.43, p.65-74, 1996.

KAPLAN, A.J., PETERSON, M.E., KEMPPAINEN, R.J. Effects of disease on the results of diagnostic tests for use in detecting hyperadrenocorticism in dogs. J Am Vet Med Assoc, v.207, n.4, p.445-451, 1995.

LÖVGREN, T., HEMMILÄ, I., PETTERSSON, K., $\boldsymbol{e}$ t al. Determination of hormones by time-resolved fluoroimmunoassay. Talanta, v.31, n.10B, p.909-916, 1984.

MACK, R.E., FELDMAN, E.C. Comparison of two low-dose dexamethasone supression protocols as screening and discrimination tests in dogs with hyperadrenocorticism. J Am Vet Med Assoc, v.197, p.1603-1606, 1990

PARADIS, M., PAGÉ, N., LARIVIÈRE,N. et al. Serum-free thyroxine concentrations, measured by chemiluminescence assay before and after thyrotropin administration in healthy dogs, hypothhyroid dogs and euthyroid dogs with dermatopathies. Can Vet J, v.37, p.289-294, 1996.

PETTERSSON, K. Comparison of immunoassay technologies. Clin Chem, v.39, n.7, p.1359-1360, 1993.

SOINI, E., KOJOLA, H. Time-resolved fluorometer for lanthanide chelates- a new generation of nonisotopic immnoassays. Clin Chem, v.29, n.1, p.65-68, 1983.

THORESEN, S.I., WERGELAND, R, MORKRID, L, et al. Evaluation of an enzymatic immunoassay for free thyroxine determination in canine serum. Vet Res Com, v.20, n.5, p.411-420, 1996. 